\title{
UNEASY LIES THE HEAD: POSTSTRUCTURALISM IN THE MIDST OF PARADIGM CONTESTATION IN APPLIED LINGUISTICS
}

\author{
Author: \\ Albert Weideman ${ }^{1}$

\section{Affiliation:} \\ 'Senior research fellow, \\ Office of the Dean: \\ Humanities, University of \\ the Free State

\section{Correspondence to:} \\ Albert Weideman \\ Email: \\ albert.weideman@ufs.ac.za \\ Dates: \\ 15 Dec 2015 \\ How to cite this article: \\ Weideman, A., 2015. \\ "Uneasy lies the head: \\ Poststructuralism in \\ the midst of paradigm \\ contestation in applied \\ linguistics". KOERS - \\ Bulletin for Christian \\ Scholarship, 80(4). \\ Available at: http:// \\ dx.doi.org/10.19108/ \\ koers.80.4.2247
}

\section{Copyright:}

(c) 2015. The Author(s)

Published under the

Creative Commons

Atribution License.
A number of recent discussions reveal a renewed unease within applied linguistics with how the field should be defined, which direction it should take, what the legitimate focuses are for work in the discipline, what themes should engage applied linguists, and which methodologies they should employ. This paper focuses on how the currently ascendant, late-postmodern paradigm within applied linguistics is dealing with, or ignoring, the challenges it faces from within postmodernism, and beyond. In its response, it is evident that the view of applied linguistics as dealing with language issues or practices makes it difficult to distinguish from linguistics, even where, often contradictorily, its supposed multidisciplinary or interdisciplinary character is invoked. It is essential to distinguish the influence that other disciplines may themselves exert on applied linguistics from the philosophical paradigms operative in those disciplines. Paradigm alignment may therefore well be mistaken for interdisciplinary influence and understandings. Given a current uneasiness with postmodernist approaches, and an expressed desire to move beyond its relativism and political agendas, poststructuralism indeed presents an important theoretical defence of late postmodernism. One problem with that defence is its often strident dismissal of other postmodernist approaches, while implying that it is the purest form of that. So the ascendancy of poststructuralism comes at a cost: the rejection of potential allies. While it may yet contribute to more responsible applied linguistic designs, its emphasis on the political and especially ethical dimensions of applied linguistic work will probably be its enduring contribution.

'n Aantal onlangse besprekings gee blyke van hernieude ongemak in die toegepaste taalkunde met betrekking tot hoe die veld gedefinieer behoort te word, watter rigting dit moet inslaan, watter fokusse legitiem is vir sy dissiplinêre werk, watter temas aangespreek moet word, en welke metodologieë aangewend moet word. Hierdie bydrae fokus op die wyse waarop die huidig toonaangewende, laat-postmodernistiese paradigma in die toegepaste taalkunde die uitdagings wat afkomstig is vanuit die postmodernisme self, maar ook van buite die postmodernisme, hanteer of ignoreer. Uit die reaksie daarop is dit duidelik dat die siening van die toegepaste taalkunde as die hantering van taalkwessies of -praktyke dit moelik maak om dit te onderskei van die linguistiek, selfs waar die toegepaste taalkunde ietwat kontradiktories homself tegelyk beroem op sy multi-of interdissiplinêre aard. Dit is verder noodsaaklik om te onderskei tussen die invloed van ander dissiplines op die toegepaste taalkunde en die filosofiese paradigmas wat werksaam is in daardie ander dissiplines. Die belyning van paradigmas oor vakgrense heen kan maklik aangesien word vir interdissiplinêre invloed, wat dit nie is nie. Gegewe die huidige ongemak met 'n postmodernistiese aanpak, asook die versugting om aan te beweeg, weg van sy relativisme en politieke agendas, is dit verstaanbaar dat die poststrukturalisme ' $\mathrm{n}$ besondere teoretiese regverdiging mag bied vir die laat-postmodernisme. Die een probleem met daardie verweer is die telkens robuuste afwysing van ander postmodernistiese aanpakke, tesame met die implikasie dat die poststrukturalisme die suiwerste vorm daarvan is. Die invloedrykheid van die poststrukturalisme kom dit dus duur te staan: dit beteken dat potensiële bondgenote verwerp word. Terwyl dit nog kan bydra tot die meer verantwoordelike ontwerp van toegepaste taalkundige intervensies, bly die meer duursame bydrae wat dit kan maak steeds die klem te wees wat dit plaas op veral die politiese en etiese dimensies van toegepaste taalkundige werk. 


\section{A FIELD WITH A MULTIPLICITY OF METHODOLOGIES AND STYLES}

Certainly not at its inception, when the modernist invocation of the 'truth' and the supposed authority of science had the upper hand, but at least over the past 30 years of its short history, applied linguistics has been characterised by a plurality of approaches and styles of scholarly endeavour (Weideman, 2013a; Rajagopalan, 2004). Since at least the last decade of the previous century, paradigmatic variation has therefore been the rule rather than the exception, with cognitivism superseding behaviourism, and itself being superseded by constructivism and, subsequently, giving way to a plethora of new perspectives, for example on what have been variously labelled communicative, strategic, semiotic, symbolic, intercultural or performative competence (Kramsch, 2015: 458; 2008: 391, 400) as ways of describing the desirable kind of ability that learners of additional languages have as their target. This veritable explosion of alternative perspectives since the 1990s may in good measure be ascribed to a turning away of applied linguistics from its modernist roots, and its embrace of the variety and differentiation so characteristic of postmodernist approaches (Weideman, 2016). That departure from its modernist beginnings has been characterised as the "social and cultural turn in Applied Linguistics" (Kramsch, 2015: 457), a shift that has given rise to increasing attention to historicity, relativity, subjectivity, reflexivity (Macbeth, 2001; Strauss, 2015), the irrational, the unjust, and the grief and pain associated with that (McNamara, 2012a: 478,480 ), along with a number of other characteristically postmodernist emphases (see too Paltridge, 2014: 100). As regards subjectivity, and specifically the interpretation of the intersubjective use of language, there is the appreciation in the 'ecological perspective' of language (Kramsch, 2008; Van Lier, 2008) of the subjective lingual factuality of human action (Weideman, 2009a: 81-83). In the ecological perspective, the 'self' is inevitably related to the 'other'; we use "staged presentations of self" in such relations (Kramsch, 2008: 391).

Perhaps as a result of this multiplicity of emphases within postmodernism (Weideman, 2003, 2007a, 2007b), there have been a number of recent reconsiderations and discussions of how the discipline must be defined or redefined, what the field may by implication legitimately focus on, which methodologies should be employed by applied linguists, what themes are current, and which future direction it should take.

So, for example, we find Paltridge's (2014) discussion in a recent

AIL A review of approaches like narrative enquiry (Bell 2002) and autoethnography (Ellis, Adams \& Bochner, 2011; Vandrick, 2009) as potential current explanations of what motivates

applied linguistic research. Similarly, a recent special issue of Applied linguistics (36/4), introduced by the new editor John Hellermann (2015), gives an overview of the discipline from the vantage points of a handful of seasoned applied linguists. Thisfollowshard on the heels of aprevious specialissue of Applied linguistics (33/5) that focussed on poststructuralism, presented as "challenging and disruptive perspectives" that embody "new modes of reasoning" (McNamara, 2012a: 481), as well as a renewed call for accountability and responsibility (McNamara, 2012b: 574). In other publications and presentations, there has been a new history of applied linguistics (De Bot, 2015), as well as the "mapping of applied linguistics" (see Meara, 2014), the latter tracing recurrent and historically important themes and trends across the major journals in the field. It is significant

that two of the contributions in the 2015 special issue of Applied linguistics, by McNamara (2015) and Kramsch (2015), feature the same authors as in the 2012 edition on poststructuralism, a clear indication of the importance currently attached in applied linguistics to that particular late-postmodernist perspective.

This paper focuses on some latent, and still largely undiscussed issues in these and similar debates, in other words on observations that are not immediately obvious to those who read and understand these discussions as merely historical treatments and information, of past, contemporary or possible future directions within the discipline. The first observation that will be dealt with below is that, within postmodernism itself, there is an ongoing contestation about potentially modernist influences that still inhibit its radicalism (McNamara, 2012a: 474; Kramsch, 2012). The second is that, with one possible but tenuous exception, poststructuralist thinking ignores its main current rival, dynamic systems theory. There remains within poststructuralism an uneasiness with the notion of 'system', with some proponents declaring it anathema, and others retaining an ambiguous perspective. The third and related observation is that there remain clear lines of demarcation between dynamic systems theory and poststructuralism, in which the political emphases of the latter appear to be the distinct and enduring contribution that poststructuralism (as most other tenets of postmodernism) will add to the design of applied linguistic solutions to language problems. The fourth observation concerns the claim by poststructuralism that other disciplines exert an influence on applied linguistics, and so implicitly provide evidence of interdisciplinarity. Such a claim may indeed stem from a twofold misunderstanding. I turn below to each of these issues.

\section{HOW POSTMODERN IS POSTMODERNISM? AND HOW ADEQUATE?}

Is characterising an approach to applied linguistic work as modernist or postmodernist merely a question of definition? There are, to be sure, a number of handy alternatives and possibilities to distinguish divergence of approach in applied linguistics, for example the positivism/postpositivism cline, or the quantitative/qualitative divide. Yet the most salient distinction, historically, does seem to be the difference in approach to doing applied linguistics that gets conceptualised in the modernism/postmodernism distinction (Weideman, 2013a: 4480; 2013b: 242). Postmodernism in this view is indeed characterised by its opposition to modernism - that goes almost without saying but it is not a static approach; rather, it embodies an evolving movement, with earlier and later interpretations. Its beginnings in applied linguistics may be 
traced, for example, to the appreciation in early ethnographic studies of different (and necessarily fragmented) perspectives, characterised by an awareness of the contextual appropriateness or inappropriateness of applied linguistic interventions, as well as by an anti-progressivist view of such design work. In those senses its association with the "New Literacy Studies" (Street, 2011; Cope \& Kalantzis, 2000) and the work of Hornberger and others (Hornberger, 1994; Hult \& King, 2011b, 2011a; Creese, 2011; McCarthy, 2011) is clear and enduring, as is the call in language teaching to go "beyond method" by seeking a "postmethod condition" (Kumaravadivelu, 1994, 2003, 2006). What is more, the initial silence on political engagement within earlier ethnographic studies related to language teaching (e.g. Watson-Gegeo, 1988) has yielded to a resounding affirmation of the necessity not only to lay bare the power differentials in organisational and institutional language arrangements (such as policies, assessments and language development interventions), but also to challenge and transform them. The critical (mostly with a capital C) and participatory styles of applied linguistics that are also characteristic of a postmodernist approach constitute an alternative to modernism by "bringing into being new schemas of politicisation" (Pennycook, 1999:335). Their philosophical starting point is highly critical of the positivist research strategies and pursuits of modernism.

In this kind of broad-brush characterisation, postmodernism in applied linguistics may therefore indeed be variously defined, also as regards its own internal evolution as an approach to doing applied linguistics, but is nonetheless sure to include similar characteristic features in both its early and its late forms. As regards the dominant approach in late postmodernism, poststructuralism, it should be included, as McNamara (2012a: 478, 481, note 3) points out in an explanatory aside, in postmodernism. What is in the same breath called 'modernist' are, however, to this later and by implication somewhat purer form of postmodernism, the very same "social critical theorists of language who are more obviously modernist, such as Bourdieu, Habermas and Halliday", whose work has informed much postmodernist effort; their failure is described as "a failure to acknowledge the radical critique of modernism implicit (and explicit) in poststructuralism" (McNamara, 2012a: 474). Halliday's confession that his systemic functional grammar originates in his "own background as a Marxist and work with our little linguistics group in the Communist Party in the fifties... searching for a Marxist linguistics" (Davies, Joseph \& Weideman, 2007: 3) therefore fails to satisfy the radical criteria demanded by poststructuralism. For Kramsch, too, the exposure of abuses of political power is but modernism (2012: 483), that could yet aspire to realising "the potential for political action opened up by a poststructuralist stance in applied linguistics" (2012: 493). Though multilinguals can be assisted by poststructuralist scholars to undertake "an ethical transformative quest... [that] challenges dominant discourses" (2012:499), the neo-Marxist Critical Discourse Analysis that gave birth to these ideas is dismissed as remaining deaf to the radical critique of its conceptions by poststructuralists (McNamara, 2012a: 479). McNamara (2012a: 478) is thus at pains to explain "how poststructuralism differs from other critical theories", and how objectionable their "muting of its critique" is (2012a: 479).

Poststructuralism, while claiming to be fully part of postmodernism, therefore seeks to set itself apart from other approaches that share with it most of the other characteristic features of postmodernism by labelling them 'modernist'. It is a distinction that is neither credible nor should it be appealing, especially to those who share an aversion to modernist hubris, "a rejection of the idea of "progress" (McNamara, 2012a: 477), technicism, and the like, all of which characterise non-poststructuralist perspectives on postmodernism at the same time that they feature in poststructuralism itself. Of all those mentioned, the outstanding feature that sets poststructuralism apart is its "critique of the idea of system" (McNamara, 2012a: 477), in fact its being "critical of all systems" (2012a: 478); the other features, especially its "sustained critique of current social, political, and cultural forms and an ethical pre-occupation with questions of justice" (2012a: 477; 2012b 574), the non-neutrality of science, and the premise of subjectivity, it shares with all other forms of postmodernism, even some of the earliest ethnographic approaches.

The claim that applied linguistic work can be "inspired by poststructuralism proper", instead of by mere "emancipatory modernism" (McNamara, 2015: 474) makes the implication unavoidable that poststructuralism is perceived as a currently purer form of postmodernism, representing "a revolutionary change" for applied linguistics (2015: 475). It certainly poses as being part of a set of "epistemological advances" (Kramsch, 2015: 458) that are inspiring improvements, for example, in "the practice of teaching languages". However, the dismissive treatment of potential allies in the quest for justice in applied linguistic designs as being thoroughly modernist or mere liberatory preambles to the 'proper' emancipation that poststructuralism will bring is at the same time a sign of an uneasiness within postmodernism. It is, to be sure, still the dominant paradigm in applied linguistics, yet the almost strident dismissal by poststructuralism of potential support may be evidence that its dominance is not secure. When I turn in the next sections to strong challengers that have emerged within postmodernist applied linguistics as well as outside of its political and ethical ambits, I shall also place those challenges within the context of a broader weariness with postmodernism across disciplines.

\section{A CURRENT CHALLENGE WITHIN POSTMODERNISM TO POSTSTRUCTURALISM}

While poststructuralism may be the pre-eminent paradigm in late postmodernism, its dominance is an uneasy reign. In fact, it faces at least two stiff challenges to continue as the most influential paradigm in applied linguistics, challenges that come from within postmodernism and from without. As has been noted in the previous discussion, poststructuralist aversion to early and mostly critical postmodernist approaches, which it labels modernist, leaves an opening for those within a more broadly conceived postmodernist approach, but 
that share the majority of political and ethical concerns that characterise, within postmodernism, the work of both poststructuralists and the rest.

Within postmodernist approaches, one strong contender for being an equally influential paradigm operative within applied linguistics presents itself in the now fully politically and ethically engaged practice of ethnography (Hult and King, 2011b, 2011a; Creese, 2011; McCarthy, 2011) already referred to above, allied as this is with the New Literacy Studies movement and the notion of educational linguistics, that is particularly concerned with power differentials and issues of institutional language policy and how these impede or facilitate language education (Spolsky \& Hult, 2008; Hult, 2010; Hult \& King, 2011b). In these variants of postmodernism, applied linguistic work acknowledges that overt and covert political agendas are operative when designs for language solutions are proposed (Hornberger \& Hult, 2008; Hult \& King, 2011b). The solutions designed and presented as the result of applied linguistic investigation are never politically or ethically neutral. In recognising that, ethnography has been at the forefront of critical approaches in postmodernist applied linguistics. Ethnographic views are therefore prominent, both in describing unequal language situations, and in bi- and multilingual language policy formulations done within the ambit of educational linguistics (Spolsky \& Hult, 2008).

What makes the dismissive treatment of potential allies by poststructuralism even more remarkable is that the ascendancy of postmodernism created a willingness to acknowledge differences and variety in theoretical approach within disciplines. It thus introduced greater tolerance and recognition of a diversity in belief and commitment in scholarly work, and in the adoption of paradigms that express those commitments. Such recognition of variation took as its first point of departure that science cannot escape self-interest and institutional coercion, and is therefore never neutral. The reason for taking non-neutrality as starting point, in opposition to the commitments of modernism, was the demonstrable immersion of disciplinary work in political power plays within disciplines, universities and the academic publishing industry. The best explanation for the strong emphasis by poststructuralism on its differences with other approaches within postmodernism therefore appears to be an intention to clarify and assert its paradigmatic superiority. That it leaves us, as a result, with the less desirable effect of intolerance of paradigmatic variation is the sacrifice it then has to make.

\section{A FURTHER CHALLENGE TO POSTMODERNISM, AND THE POSTSTRUCTURALIST RESPONSE}

The dominance of postmodernism in applied linguistics faces a second challenge, from outside postmodernist approaches, from dynamic systems theory (DST), sometimes referred to as complex systems theory (De Bot, Lowie \& Verspoor 2007; Beckner, Blythe, Bybee, Christiansen, Croft, Ellis, Holland, Ke, Larsen-Freeman \& Schoenemann. 2009; Ellis \& Larsen-Freeman, 2006; Larsen-Freeman \& Cameron, 2008; Lee, Mikesell, Joaquin, Mates \& Schumann, 2009).
Though one may in passing imagine that DST is yet another variation of postmodernism, that thought will soon be dispelled when its typically modernist starting points, specifically its affinities with the natural sciences and computer modelling of language, are revealed. While McNamara's intention (2015; McNamara \& Roever, 2006: 254) is that applied linguistics should break down the disciplinary walls between it and the humanities, the emergentist and organicist views of language of DST (Weideman, 2009b; 2013b) are clearly derived from the natural sciences rather than the humanities. Add to that the adherence of DST to concepts of system and structure, and it is clearer still that this sets it apart from radical postmodernism. We have noted above how an important mark of poststructuralism, the currently ascendant version of postmodernism, is "a critique of the idea of system, and a rejection of belief in the idea of 'progress'" (McNamara, 2012a: 477).

Not only does poststructuralism reject the concept of system, but it also shares with other postmodernist approaches in applied linguistics a concern with political justice and ethicality. Despite claims that the dynamic emergent processes observed by DST possess the potential or "possibility of freedom" (Larsen-Freeman \& Cameron, 2008:9), there is nothing close to such concerns in the manifestations of DST within applied linguistics. Moreover, the views of those working within a DST paradigm on human agency are a world apart from the transformative human action foreseen by postmodernism, not only in its critical, but especially in its poststructuralist conceptualisation. DST has little to say about the overtly political agenda of postmodernism in applied linguistics.

As to the notion of progress, there is the distinct implication within discussions emanating from a DST or allied perspective that improvement and progress are attainable if such a perspective is adopted, motivated as it is "by the belief that our interests in language can better be furthered when it is conceived of as the emergent properties of a multi-agent, complex, dynamic, adaptive system..." (Ellis \& Larsen-Freeman, 2006: 558).

How do poststructuralist applied linguists respond to the challenge presented by DST? It is interesting, but no coincidence, that in referring to work from a DST and complexity theory perspective, Kramsch (2008:391; 2015:456) very carefully avoids the use of the word 'system', preferring the terms 'science' or 'emergentism' instead. Also, in her interpretation of the multiplicity of lingual meanings, recursiveness, non-linearity, the fractal nature of relations, emergent meaning, and so forth (Kramsch, 2008:404), we find none of the precision with which these terms are used within DST, but rather a reluctance to explain their meaning within that other paradigm. At best, one may speculate that involving notions associated with DST may in this instance represent a willingness to embrace the intuitive wisdom of observations made from a DST perspective, but then with an accompanying reluctance to adopt (or understand) the paradigm fully. Remarkably, however, these discussions come from only a single, though influential, scholar working within the poststructuralist paradigm; amongst other adherents there is silence, and, though poststructuralism shares the same belief 
in improvement, progress, and 'advancement' as we have noted above, DST is ignored. Perhaps it can be said that because both DST and poststructuralism believe that theirs is the better perspective, their rivalry in influencing the course of applied linguistics demands this.

How do those working within DST or other paradigms in turn respond to poststructuralism? Perhaps a recent book, dedicated to one of the most prolific researchers in second language acquisition studies, Teresa Pica (Mayo, Mangado \& Adrian, 2013), gives an indication. It contains studies on contemporary insights into second language learning from, amongst a number of others, generativist, systemic functional grammar, Vygotskyan, usage-based and DST perspectives. There is very little reference (except, remarkably, in the contribution on DST and in one other) to any prominent proponent of poststructuralism, and then usually to work that such scholars undertook without explicitly adopting or before fully adopting a poststructuralist position. The lack of a consolidated bibliography makes this observation difficult to verify more exactly, but the impression certainly is that the favour of being ignored within poststructuralism is possibly being returned.

It remains uncertain, of course, how this rivalry will play itself out within institutions and scholarly opportunities for publication, but one knows that it becomes acute when one observes a weariness setting in with the relativism and contradictions of postmodernism that one detects, for example, in calls for a (post)postmodernist perspective (Weideman, 2013b:246). Perhaps DST, given the equally strong convictions that drive it, may just be the more attractive postpostmodernist paradigm.

The rivalry between poststructuralism and DST will be lost on those who read the discussions being analysed here as merely information about (admittedly different) paradigms. The kernel of the analysis is the historical struggle within the discipline of applied linguistics for influence; applied linguistics is by no means a happy disciplinary family. The paradigm choice (or institutional coercion) that new entrants into the discipline face is an under-discussed theme in the literature. Where currently rival paradigms ignore one another, new entrants into applied linguistics are shielded from exposure to alternatives. Institutional power, the organisational blight identified by, and the subsequent target of postmodernist activism, favours the political dominance of the currently ascendant paradigm within a university, scholarly association, publishing house, or other site of power, even if that dominant paradigm were postmodernism or its late-postmodernist variant, poststructuralism, whose proponents build their scholarly reputations around the exposure of political domination.

\section{INTERDISCIPLINARITY OR MUTUALLY ALIGNED PARADIGMS?}

Among the various disciplines usually listed by proponents of poststructuralism in applied linguistics that have, or should have, an influence on our work, there are psychology, cultural studies, communication studies, sociology, anthropology (Kramsch, 2015: 456, 458, 461), literary theory, and ethnography
(McNamara, 2015: 466, 475). The sometimes explicit, but often unstated implication of these claims is that such influences may provide evidence of the interdisciplinary character of applied linguistics. There is some ambiguity, however, in the specification of what the influence of other disciplines actually is, and how the disciplinary demarcations, or their abandonment (McNamara \& Roever, 2006: 254) should be approached.

Ironically, the ambiguity stems from an adherence, within applied linguistics, to the idea of linguistics constituting a privileged source of theory (McNamara, 2015:471), and of an "unwavering determination" within applied linguistics "to maintain strong links to linguistics" (Kramsch, 2015:459). That, of course, to a larger extent than is credible, contradicts its simultaneous claim that applied linguistics is actually an interdisciplinary domain of work (McNamara, 2015:473; Weideman, 2016). This is a first source of possible misunderstanding in defining applied linguistics, and there are historical reasons for this contradiction. The dominance within linguistics of generativism, along with its purist definition of linguistics (Weideman, 2013c), alienated many scholars who wished to work within linguistics, denying them academic opportunity, access to resources, publication outlets, and the like. Nonetheless, it can be argued that both the analysis of the regulative elementary linguistic ideas investigated by sociolinguistics, including discourse analysis, text linguistics, and conversation analysis, and the analysis of complex linguistic ideas, such as the study of the origin, development, maturation and possible loss of language accomplished by language acquisition research, belong squarely to linguistics (Weideman, 2009a). Historical reasons for their finding disciplinary shelter elsewhere, more

likely than not in applied linguistics, does not invalidate the argument that systematically and philosophically, they are linguistic sub-disciplines. What is more, defining applied linguistics itself with a primary reference to linguistics obscures the systematic distinction that they may best be defined with reference to the modal angles - in this case, respectively, the technical dimension of design that delimits applied linguistic plans and solutions, and the lingual aspect of expression that circumscribes linguistic analyses - from which their analyses seek to explain the concrete phenomena that operate within these modalities, including language (as an object) and subjective lingual factuality. Invoking 'language' (sometimes in capital letters) as the defining characteristic of either discipline is therefore less useful (Weideman, 2013c), and likely to end up in contradictions.

A sensible interpretation of recent claims regarding interdisciplinarity would be that the new sources of theory for applied linguistics recognised by poststructuralism (McNamara, 2015:466) are not themselves disciplinary influences as much as they are paradigmatic similarities across disciplines. That insight may serve to eliminate a second potential misunderstanding. It is essential, therefore, to distinguish the influence that other disciplines may themselves exert on applied linguistics from the philosophical paradigms operative in those disciplines. Paradigm alignment across 
all of those mentioned may therefore well be mistaken for interdisciplinary influence and understandings. Without an acknowledgment of this, and of the disciplinary specificity of applied linguistics, both postmodernist and post-postmodernist emphases in the field may find themselves in an unproductive space, mired in contradiction.

\section{PRODUCTIVE DESIGN, RESPONSIBLE DESIGN}

The productivity of applied linguistic work is recognised by adherents of a variety of paradigms as a goal of the discipline. Such disciplinary involvement stems from an enduring concern with designs to improve the language teaching provided to the vulnerable (Kramsch, 2015: 457), whether they be disadvantaged, members of minority groupings, in need of health care, or work opportunity. If these designs can be accomplished by providing theoretical justifications for them, they have the further potential to become responsible designs that also take into consideration those issues of justice, fairness and compassion in which they are embedded.

The contribution of postmodernism to justice and compassion in applied linguistic designs, not only in its late-postmodernist form, poststructuralism, but also in its earlier postmodernist manifestations, has undoubtedly made those who make such plans aware that there are more dimensions to their planned interventions and efforts than merely providing a 'better' theoretical rationale for them. That, and being accountable to the public, may be its enduring achievement, and in that sense DST, for all its promise, may still have something to learn from postmodernism. We should acknowledge that each paradigm brings with it the possibility of reductionism; even the antireductionist intentions of DST may stem from an emergentism, an overestimation of the organic or biotic mode of experience. Similarly, if in postmodernist orientations everything is reduced to political and cultural conflicts of power and influence, we again have an undesirable reductionism at work. Paradigm shifts should therefore be recognised, less to determine which is 'better' or likely to lead to improvements in practice, but as potentially complementary and mutually contributing insights into the responsible design of the prime applied linguistic artefacts: language policies, language curricula and language assessments. In all of these designs, poststructuralism and DST still need to demonstrate more clearly their relevance to practice, and to do so on scale.

\section{REFERENCES}

BECKNER, C., BLYTHE, R., BYBEE, J., CHRISTIANSEN, M.H., CROFT, W., ELLIS, N.C., HOLLAND, J., KE, J., LARSEN-FREEMAN, D., \& SCHOENEMANN, T., 2009, 'Language is a complex adaptive system: Position paper'. Language learning 59 (supplement 1): 1-26.

BELL, J.S., 2002, 'Narrative enquiry: More than just telling stories', TESOL quarterly 36(3): 207-213. DOI: $10.2307 / 3588331$.

COPE, B., \& M. KALANTZIS (eds.), 2000, Multiliteracies: Literacy learning and the design of social futures. Routledge, London

CREESE, A., 2011, Making local practices globally relevant in researching multilingual education. In HULT, F.M. \& KING, K.A. (eds.), Educational linguistics in practice: Applying the local globally and the global locally, 41-55, Multilingual Matters, Bristol.

DAVIES, A., \& ELDER, C. (eds.), 2004, The handbook of applied linguistics, Blackwell, Oxford.

DAVIES, A., JOSEPH, J., \& WEIDEMAN, A.J. [transcription by K. MITCHELL], 2007, The Pit Corder colloquium: Interview with Michael Halliday and Ruqaiya Hasan, BAAL, 2007, Conference proceedings: 3-10, University of Edinburgh, Edinburgh.

DE BOT, K. 2015, A history of applied linguistics: From 1980 to the present, Routledge, Oxford.

DE BOT, K., LOWIE, W. \& VERSPOOR, M., 2007, 'A dynamic systems theory approach to second language acquisition', Bilingualism: Language and cognition 10(1): 7-21.

ELLIS, C., ADAMS, T.E. \& BOCHNER, A.P., 2011, Autoethnography: An overview. Forum: Qualitative Social Research 12(1): 1-12. [Online]. Available http:// www.qualitative-research.net/index.php/fqs/rt/printerFriendly/1589/3095. Accessed 28 July 2015

ELLIS, N.C. \& LARSEN-FREEMAN, D, 2006, Language emergence: Implications for applied linguistics - Introduction to the special issue, Applied linguistics, 27(4):558-589. [Online]. Available doi:10.1093/applin/aml028. Accessed 17 June 2015.

HELLERMANN, J., 2015, Three contexts for my work as co-editor: Introduction to the special issue', Applied linguistics 36(4): 419-424.

HORNBERGER, N., 1994, 'Ethnography', TESOL quarterly 28(4): 688-690.

HORNBERGER, N. \& HULT, F.M., 2008, Ecological language education policy, in SPOLSKY, B. \& HULT, F.M. (eds.) The handbook of educational linguistics, 280296, Blackwell, Malden, MA.

HULT, F.M. (ed.), 2010, Directions and prospects for educational linguistics, Springer, Dordrecht.

HULT, F.M., \& KING, K.A., 2011a, Introduction: Global and local connections in educational linguistics, in HULT, F.M. \& KING, K.A. (eds.), Educational linguistics in practice: Applying the local globally and the global locally, xviii-xxvi, Multilingual Matters, Bristol.

HULT, F.M., \& KING, K.A. (eds.), 2011b, Educational linguistics in practice: Applying the local globally and the global locally, Multilingual Matters, Bristol.

KRAMSCH, C., 2008, 'Ecological perspectives on foreign language education', Language teaching 41(3):389-408.

KRAMSCH, C., 2012, Imposture: A late modern notion in poststructuralist SLA research', Applied linguistics 33(5):483-502.

KRAMSCH, C., 2015, 'Applied linguistics: A theory of the practice', Applied linguistics 36(4): 454-465. 
KUMARAVADIVELU, B., 1994, 'The postmethod condition: (E)merging strategies for second/ foreign language teaching', TESOL quarterly 28(1): 27-48.

KUMARAVADIVELU, B., 2003, Beyond methods: Macrostrategies for language teaching, Yale University Press, London.

KUMARAVADIVELU, B. 2006. Understanding language teaching: From method to postmethod, Lawrence Erlbaum Associates, Mahwah, New Jersey.

LARSEN-FREEMAN, D. \& CAMERON, L., 2008, Complex systems and applied linguistics, Oxford University Press, Oxford.

LEE, N., MIKESELL, L, JOAQUIN, A.D.L., MATES, E.W. \& SCHUMANN, J.H., 2009, The interactional instinct: The evolution and acquisition of language, Oxford University Press, Oxford.

MACBETH, D., 2001, 'On "reflexivity" in qualitative research: Two readings and a third' Qualitative Enquiry, 7(1):35-68. DOI: 10.1177/107780040100700103.

MAYO, M.D.P.G., MANGADO, M.J.G. \& ADRIAN, M.M. (eds.), 2013, Contemporary approaches to second language acquisition, John Benjamins, Amsterdam.

MCCARTHY, T.L., 2011, Unpeeling, slicing and stirring the onion: Questions and certitudes in policy and planning for linguistic diversity in education, in HULT, F.M. \& KING, K.A. (eds.), Educational linguistics in practice: Applying the local globally and the global locally, 109-125, Multilingual Matters, Bristol.

MCNAMARA, T., 2012a, 'Poststructuralism and its challenges for applied linguistics', Applied linguistics 33(5): 473-482.

MCNAMARA, T., 2012b, 'Language assessments as shibboleths: A poststructuralist perspective', Applied linguistics 33(5): 564-581.

MCNAMARA, T. \& ROEVER, C., 2006, Language testing: The social dimension, Blackwell, Malden, MA.

MEARA, P., 2014,_lognostics: Tools for vocabulary research. Available: http:// www.lognostics.co.uk/. Accessed 1 December 2014.

PALTRIDGE, B., 2014, 'What motivates Applied Linguistics research?', AILA Review, 27: 98-104. Available DOI: 10.1075/aila.27.05pal.

PENNYCOOK, A., 1999, Introduction: Critical approaches to TESOL', TESOL quarterly (Special topic issue: Critical approaches in TESOL) 33(3):329-348.

RAJAGOPALAN, K., 2004, The philosophy of applied linguistics, in Davies, A. \& Elder, C. (eds.): 397-420.

SPOLSKY, B. \& HULT, F.M. (eds.), 2008, The handbook of educational linguistics, Blackwell, Malden, MA.

STRAUSS, D., 2015, Between postmodernism, positivism and (new) atheism, Koers 80(1), Art. \#2209. [Online]. Available http://www.koersjournal.org.za/index. php/koers/article/view/2209/pdf.Accessed 13 November 2015.

STREET, B., 2011, New literacy studies and the continua of biliteracy, on Hult, F.M. \& King, K.A. (eds.), Educational linguistics in practice: Applying the local globally and the global locally, 59-67, Multilingual Matters, Bristol.

VANDRICK, S., 2009, Interrogating privilege: Reflections of a second language educator, University of Michigan Press, Ann Arbor, MI.

VAN LIER, L., 2008, Ecological-semiotic perspectives on educational linguistics, in Spolsky, B. \& Hult, F.M. (eds.), 2008: 596-605.

WATSON-GEGEO, K.A., 1988, 'Ethnography in ESL: Defining the essentials', TESOL quarterly, 22(4): 575-592.

WEIDEMAN, A., 2003, Towards accountability: A point of orientation for post-modern applied linguistics in the third millennium', Literator 24(1):1-20.

WEIDEMAN, A., 2007a, The redefinition of applied linguistics: Modernist and postmodernist views', Southern African linguistics and applied language studies
25(4): 589-605.

WEIDEMAN, A., 2007b. Towards a responsible agenda for applied linguistics: Confessions of a philosopher, Per linguam, 23(2):29-53.

WEIDEMAN, A., 2009a, Beyond expression: A systematic study of the foundations of linguistics, Paideia Press, Grand Rapids, MI, in association with the Reformational Publishing Project.

WEIDEMAN, A., 2009b, Uncharted territory: A complex systems approach as an emerging paradigm in applied linguistics, Per linguam, 25(1): 61-75.

WEIDEMAN, A., 2013a, Positivism and postpositivism in applied linguistics, in C.A. Chapelle (ed.), The encyclopedia of applied linguistics, Vol. 7, pp. 4479-4485, Wiley-Blackwell, Oxford. ISBN: 978-1-4051-9473-0. Also [Online]. Available as entry DOI: 10.1002/9781405198431.wbeal0920.

WEIDEMAN, A., 2013b, 'Applied linguistics beyond postmodernism', Acta academica, 45(4):236-255.

WEIDEMAN, A., 2013c, 'The modal delimitation of the field of linguistics', Journal for Christian scholarship, 49(4):95-122.

WEIDEMAN, A., 2016, Applied linguistics and responsible design: Foundational questions in language education, Forthcoming from Springer. 